\title{
PROSPECTING THE CULTURE OF THE SÁMI PEOPLE THROUGH TOURISM: An Experience in the City of Tromsø, Norway
}

\author{
Joelma Monteiro de Carvalho a \\ Luciano Torres Tricário ${ }^{b}$
}

\begin{abstract}
This report focuses on different forms of tourist attraction of the Sami indigenous people in the city Tromsø/Norway, such as identity marks and maintenance of traditions. The general objective is to analyse signs as symbolic elements of the Sami people, showing their potential for indigenous ethnic tourism. We conducted a survey of tourist attractions, and verified how this service is provided for tourists. This study uses as methodological and theorical perspective that is exploratory in nature, according to Husserl's phenomenology (2001), with strategies of ethnography (MATTOS, 2011) and Peirce's semiotics (2011). This research took place in Tromsø/Norway city, which is located 350 kilometers north of the Arctic Circle and is home to the Sami people. The techniques of interlocution with those involved resulted in field annotations, and the techniques of participant observation, open-ended interview, pictures and audio recordings with ten participants were also used. Besides the interviews, documents were studied, such as Convention 169 of the International Labor Organization (ILO) and the Sami legislation. It was observed, as a result of this research, that the city of Troms $\varnothing$ in Norway has evident tourist potential through the culture of the Sami people. The tourist attractions are varied, such as watching the Northern Lights, reindeer herding, and listening to stories of ancestry closely connected to nature, in a dialogic relationship between cultural tradition and science. It was also found that these tourist attractions are carried out responsibly, with sustainability in mind.
\end{abstract}

Keywords: Sami people;

Experience;

Tromsø;

Norway;

Indigenous Ethnic Tourism. 


\section{INTRODUCTION}

This report is an excerpt of field research carried out as part of an ongoing doctoral thesis for the Tourism and Hotel Management Program of the University of Vale do Itajaí (Univali). In this context, gathering knowledge of tourism activities developed with the Sami people in the city of Tromsø (Norway) was challenging. Some of the difficulties encountered during this investigative journey were the complex travel logistics, the different language and currency, and the cold climate.

Norway is a country that has grown with tourism, mainly due to elements related to the landscape and the mythology of the Sami people - a term that "refers to several ethnic groups and not to a single people that is constituted in a unit expressed in the form of a nation: today, 10 different ethnicities are recognized" (LEHTOLA, 2005, p. 11). The general objective of the study was to analyse signs as symbolic elements of these people, highlighting their potential for indigenous ethnic tourism.

From a conceptual point of view, in relation to ethnic tourism, Berghe (1980, p. 223) states that "it is a form of tourism where the culture and exoticism of the natives are the main tourist attraction", and this tourism occurs in a preserved and differentiated space. This thinking is generated mainly by the tourist's interest in new and different cultural experiences and the desire to interact with ethnic groups, adding to their knowledge.

First, we identified the tourist attractions and how services are provided to tourists. With regard to the tourist attractions, these are mainly natural, perceived in the landscape that presents characteristics typical of the region, such as the beautiful fjords, the opportunity to see the Northern Lights, learning about culture of the Sami people, and feeding reindeer, among other activities.

It was observed that services provided to tourists are innovative, supported by technologies. An example is the use of online platforms for ticket purchases. Another is the use of a weather forecasting app that helps identify the Aurora Borealis (Aurora forecast in $3 d$ ). It is also possible to make online payment for services, and there is an app that shows departure and arrival times at the bus and metro terminals. We found that there are TV monitors on buses and metros, where travelers can see the exact arrival and departure times. For tourists, transport services can be paid for via the app, or by purchasing disposable cards that can be used as necessary. All streets are signposted in both Norwegian and Sami, and identity signs of the reindeer, the mythical animal of the people, can be seen everywhere.

Symbolically, animals appear with greater frequently and diversity, both in mythology and iconography, as highlighted by Oliveira (2016, p. 86). Thus, when walking through the streets of the city of Tromsø, we saw stores decorated with animals representing the Sami culture. We also saw live reindeer (Rangifer tarandus) being herded through the streets.

Figure 1 - Aerial view of the city of Tromsø / Norway

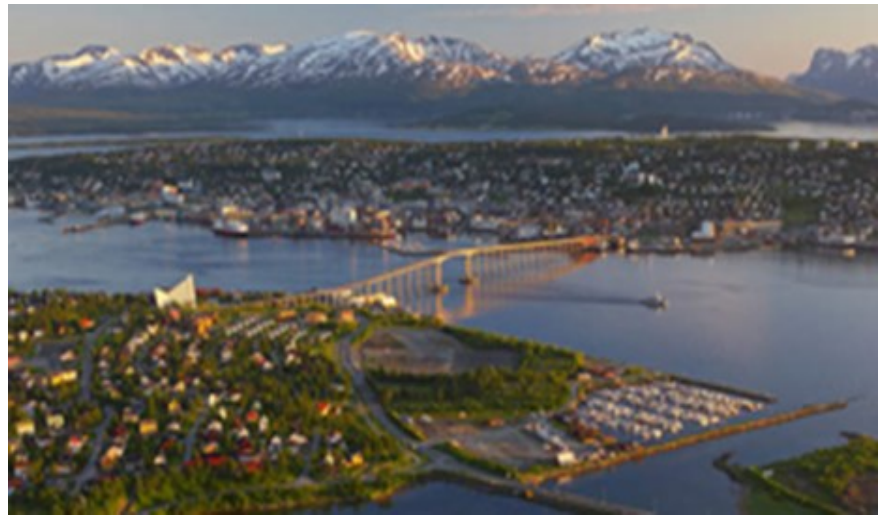

Source: VisitTromsø Agency (2020).

As Figure 1 shows, nature is an integral part of the daily lives of the inhabitants of Norway. The sea, the forest and the fjords are naturally inviting, and delight both locals and foreigners alike. Tromsø is a city that has implemented socially, economically, culturally and environmentally responsible tourism. It has a system for cleaning and selective waste collection, and there are incentives to exchange and reduce public taxes. Animals inhabit or regularly pass through the urban spaces, where it is possible to see birds and reindeer. According to Mrs. Wilqui Dias, aged 32 years, one of the interview participants and residents of Tromsø, "whenever a driver sees rein- 
deer on the streets, he will immediately stop to let them pass by".

Reindeer are considered a mythical, legendary animal of beauty and grace, besides having commercial value among the Sami indigenous peoples. They are used as food, and their leather, horns and bones are used to make utensils and handicrafts. The horns are also widely used in the manufacture of cutlery, handles, knobs, and shirt buttons, among other objects.

This report will contribute to a vision of indigenous ethnic tourism carried out in a European country that works with innovation, quality and tourist satisfaction, based on the pillars of sustainability: economy, environment, society and culture.

\section{PROBLEM AND RELEVANCE}

The questions that led us to study the Sami people were: what services are linked to the cultural tradition of the Sami people? Which of these are offered to tourists? Do these services refer to the only indigenous people in the Arctic? and Do the mythical symbols of the cultural tradition of the Sami people have tourist value?

The mythological world of the Sami people is represented by gods, and brings, in its imaginary, representations that have been passed down over several eras. "In the past, they worshiped the Great Mother, who manifested herself in forests, caves, stones, rivers and animals, revering her different personifications [...]" (FAUR, 2014, p. 572). Sami considered nature spirits to be their ancestors, and often communicated through the shaman (FAUR, 2014). However, Mrs. Sami Unni Lundstedt (2020) reports, with a feeling of sadness, that those who sought the shaman suffered harsh penalties; "History reveals that, in the 1600s, many Sami were sacrificed and burned at the stake, as their practices were considered witchcraft". This story is now retold for the benefit of tourists seeking to learn about the cultural tradition of the people, appropriating the knowledge and flavors of the culture.

Through this survey of the activities developed by the Sami, it is hope that this work will bring new scientific investments with the peoples of the Arctic. Norwegian universities are currently building an intelligent data- base on the Sami people.

\section{METHODOLOGY}

For immersion in the Sami culture, the journey to reach the city of Troms $\varnothing$, in northern Norway, had several stages. We took a phenomenological approach, using the strategies of ethnography and semiotics.

Phenomenology "is an investigation in which the researcher identifies the essence of human experiences, with respect to a phenomenon, described by the participants" (CRESWELL, 2010, p. 38). In the phenomenological judgment proposed by Husserl, an elimination of preconceived notions in relation to the nature of the facts is required, in a descriptive and dialogical relationship between the researcher and the participant (DARTIGUES, s. D.; MERLEAU-PONTY, 1999). The Husserlian proposal seeks to apprehend the thing itself, that is, the phenomenon under study. Ten interviewees took part in the research: four men and six women, aged between 18 and 65 years old, living in the city of Tromsø. Open-ended interviews were applied, as well as participant observation, conversation, and taking photographs, and a field diary was filled out. The interviews and field notes were outlined, prompting "living memories" at the time of the historical and poetic narrative (RICOEUR, 2010, p. 113).

Regarding the interview instrument, like all research, there was a certain limitation in making an ethnographic approach in that the informants were somewhat shy and wary. In this case, one of the main elements of data collection was "observing the participants behavior" (CRESWELL, 2010, p. 42). Those who agreed to be recorded and photographed signed the documentation required by the Research Ethics Committee (CEP).

In the ethnographic field, we observe "the ways in which these social groups or people conduct their lives in order to reveal the meaning of everyday life, in which people act" (MATOS, 2011, p. 51). In addition, writing documentation, even in other languages, was important, as fieldwork is not only that 
which interacts with the interlocutor (CRESWELL, 2010). With regard to the analysis of qualitative data, this was carried out in a simplified, interpretive way, focused on interpretation in the light of semiotics, in a relation between the sign, the object, and its interpretant (PEIRCE, 2010). The reading initially focused on written documents, such as articles, theses and digital platforms. Documents in text form were read, summarized and tabulated by year and author. The interviews were transcribed and analyzed, and the results were organized into categories and typologies, then into themes for the composition of the writing. Based on these results, this text was syntactically structured. The categories were divided by: type of sign, type of nature, and mythological type.

In terms of ethical issues, the participants were assured the right to freely express themselves regarding the images and statements. One informant did not want the interview to be recorded as he was unable to answer the questions; nevertheless, we respected his desire to participate, as recommended by Creswell (2010). Others agreed to the interviews by signing an Informed Consent Form, as authorized by the CEP (CAAE - 14818919.2.0000.5016).

\section{RESULTS AND DISCUSSIONS}

Convention 169 of the International Labor Organization (ILO, 2004) on Indigenous and Tribal Peoples, Article 7 , states that governments should value indigenous activities in the economic, social, cultural, spiritual and environmental areas, giving appropriate conditions to be developed.

In the cultural and spiritual bias, among various peoples of humanity, mythology is closely linked to the identity of a people. It is in mythology that the culture of a people is born, and it is through their mythology that the Sami people dialogue with the sacred, which comes from Mother Nature, energizing the soul and feeding the creative spirit.

During this study, we observed the presence of sign elements of the Sami people and a close connection to Mother Nature linked to the city of Tromsø.

During the ethnographic field work, we noted the sale of handicrafts, and stores selling stuffed animals referring to the mythology of the people. Another im- portant point was sustainability, raising environmental, economic, social and cultural issues that generate income for the indigenous people.

\section{THE EXPERIENCE IN INDIGENOUS ETHNIC TOURISM}

On a cold day, with a temperature of minus 4 degrees, we set out on one of the experiences, heading in the direction of the Sami hut. The visit started at $18 \mathrm{~h}$, Tromsø time. The landscape was gray and the sun had not yet set.

We left our seafront hotel in the city. The journey to the indigenous community lasted 45 minutes, with an indigenous Sami driver, known as a noaidi, which would be equivalent to a tribal shaman. Our journey was flanked on either side by picturesque fjords and wild forest.

In Bahl's (2016) view, ethnic tourism is comprised of the results of two types of feelings. The first is linked to social aspects, culture and identity; the second is linked by means of disseminating the existence of an ethnic group, aiming at its recognition and insertion in a national or international context.

Arriving at the village, we were received by a Sami lady, and a traditional yoik was sung by the elders, led by the ladies as the keepers of tradition. Next, an explanation was given of the principles of what it means to be Sami. This was accompanied by refreshments, tea, and a juice made from red and black wild berries. The Sami lady, Trine Marit, told us in an interview that "shamanism involves the spirituality that revolves in the drumming of the drum in harmony with nature and spirits, echoed by the yoiks". This moment is greatly looked forward to by tourists seeking to experience the Sami culture.

After the arrival ritual, reindeer soup (bidos) was served, well-seasoned with native herbs, cooked with local potatoes and carrots, accompanied by flatbred, a finely-textured, well-baked bread.

In this food ritual typical of the Sami people, we saw elements of the culture through singing and drumming, in a language articulated to the gods in cosmic harmony. Ligiéro (2011, p. 155) emphasizes that "singing, dancing and drumming are the basis of different ritual celebrations". Food was served around the 
fire, and people hummed while eating the feast.

With regard to the representation of animals, we highlight the figure of the reindeer, which biologically, belongs to the deer family Cervidae, a family of ungulate artiodactyl, ruminant animals of the same group as doe, elk and caribou. Reindeer live in silent herds at high latitudes and are magnificently adapted to the arid climate and very low temperatures. They are hardy herd animals that can withstand open skies on cold nights, when temperatures can reach as low as 45 degrees in winter. For the Sami, the reindeer is the essence of their being. Their bravery and resistance has led the Sami to persist and fight for the environment, and keep the species alive.

In the city, all services rely on the use of technologies via the Internet, such as the issue of travel tickets, for which full details are given, including the departure time, the route, the journey time, the food to be served and the activities to be carried out. Walking through the streets of Tromsø, it is clear that the city is geared up for tourism. Maps of the city and itineraries are available in all the stores, and there are many travel agencies offering various tourism services.

The inhabitants generally work to a schedule that is dictated by the seasons. Thus, in each season, the services offered by the travel agencies will differ. The costs of trips and activities range from two hundred to four thousand Norwegian kroner, depending on the season and the service offered. The services and their respective costs are shown in Table 1.

Table 1 - Examples of Services offered by VisitTromsø

\begin{tabular}{l|c|c|c|c}
\hline Services & $\begin{array}{l}\text { Norwegian } \\
\text { Currency }\end{array}$ & $\begin{array}{l}\text { Brazilian } \\
\text { Currency }\end{array}$ & Group & Duration \\
\hline $\begin{array}{l}\text { Watching } \\
\text { the Nor- } \\
\text { thern Lights }\end{array}$ & 4000 & 2000 & 10 & $5 \mathrm{~h}$ \\
\hline $\begin{array}{l}\text { Experience } \\
\text { of Sami } \\
\text { ethnic- } \\
\text { people tou- } \\
\text { rism }\end{array}$ & 2400 & 1200 & 10 & $3 \mathrm{~h}$ \\
\hline $\begin{array}{l}\text { Trip to the } \\
\text { fjords }\end{array}$ & 2200 & 1100 & 20 & $5 \mathrm{~h}$ \\
\hline
\end{tabular}

\begin{tabular}{l|l|l|l|l}
$\begin{array}{l}\text { Whale watching } \\
\text { trip }\end{array}$ & 3200 & 1600 & 20 & 3 \\
\hline Sami Museum & 200 & 100 & 5 & $2 \mathrm{~h}$ \\
\hline Reindeer herding & 200 & 100 & - & 1 \\
\hline
\end{tabular}

Source: Elaborated by Carvalho (2020).

Having considered the dynamics of the costs of tourist services, which are quite variable in relation to those in Brazil, we turn to the calendar (Figure 2), which shows the seasons of the year and the respective temperatures in each periods. Each season features a different type of tourist. In the fall, for example, the tourist profile comprises visitors aged 30 years or older, usually from countries to the East. Elderly tourists, over 60 years of age, make up $80 \%$ of tourists, according to the management of the Visit Tromsø agency and the Polari museum.

Figure 2 - Annual calendar

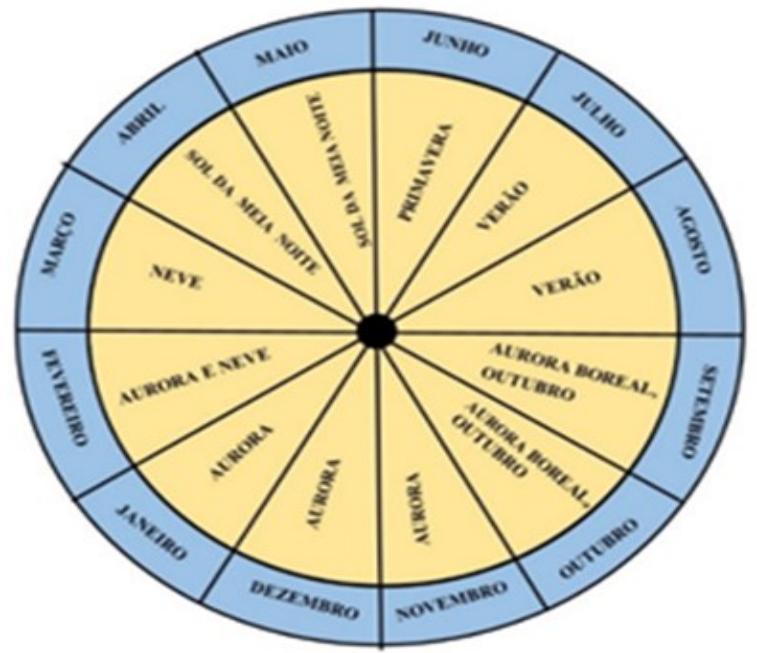

Source: Carvalho (2019).

The mythological world is a mark that signals data from the cultural history of the Sami and represents a substantial part of their identity. "History, legend and myth play an important role in time and space, functioning as a unified rebirth, highlighting the relationships between Man, Nature and Spirit" (DORSCH, 2017, p. 23). Myths tell the story of the "inter-world" journey of the Sami 
ancestors, through narratives.

\section{FINAL CONSIDERATIONS}

Based on the report presented, it was seen that the culture of the Sami people is highly valued in the city of Tromsø, and tourism services sought by visitors include experience of Sami communities.

The study also showed successful practices in city tourism, where cultural traditions have, over time, been reinvented to preserve the memory and culture of the people, as well as their linguistic and non-linguistic signs (DORSCH, 2017). We saw expressions through tribal songs, rock paintings, graphics, clothing, and food and, above all, through the practices of reindeer herding and being a Sami person, valuing the human aspects of nature, customs, and habits, as marks of the indigenous identity of that country.

We point out that investments in Sami communities are necessary in Tromsø, for example, in communities affected by mining companies that are threatening their right to herd reindeer, as signaled by Tsiouvalas (2020), which could also affect the practice of ethnic tourism. Promoting ethnic tourism that generates resources for those responsible is no easy task; it requires balance, consideration and planning. However, stakeholders should be aware of the impacts that, when not managed responsibly, can cause disruptions in the culture of the people, forcing them to migrate to cities in search of a better quality of life

One of the barriers to understanding the phenomenon in the field of ethnic tourism in Tromsø was the Norwegian language spoken in the city. On the other hand, access to indigenous peoples occurs through tourism agencies, with an interface of technologies, striving for quality of services and tourist satisfaction.

One limitation of the research field was the unavailability of some of the participants for the interviewees, as the Sami are a shy people, and wary of foreigners. As practical implications, it was seen that indigenous ethnic tourism is a growing market, in which "the visual representations that transcend the simple sign, and the meaning, depend on rational interpretations that are charged with affection and dynamism" (LANGER, 2010, p. 2-3). Thus, the culture of the Sami people is explored through nature, reindeer herding, watching the Northern Lights, and other mythical elements that are attractive to indigenous ethnic tourism, combined with the nature and mythology of the Sami people.

It was found that the Sami people are well-organized, with their own Parliament where Sami policy is discussed in a sustainable way, using the principles of nature consciously for the benefit of planetary life, as recommended by the 169/ILO convention. Therefore, the culture has awakened to responsible ethnic tourism, and it is valued and respected on a daily basis, by the people of the city of Troms $\varnothing$, and by the Norwegian government. Finally, new studies are needed, to explore these issues further, not only in Norway but also in Brazil.

\section{REFERENCES}

BAHL, M. Dimensão cultural do turismo étnico. In: A. P. Netto; M. G. dos R. Ansarah, (Eds.). Segmentação do mercado turístico (121-140). Barueri: Manole, 2016.

CRESWELL, J. Projeto de Pesquisa métodos qualitativos, quantitativos e mistos. Tradução Magda Lopes. 3aed. Porto Alegre: Artmed, 2010.

DARTIGUES, André. $\mathbf{O}$ que é a fenomenologia? Tradução de Maria José J. G. de Almeida. 32 ed. Editora Moraes Ltda. São Paulo, 1999.

DORSCH, Laura Lou Peres. A Objectificação da Cultura Sámi: Adaptabilidade no Tempo e Reconhecimento da Identidade no Norte da Sápmi Norueguesa. Dissertação de Mestrado. Instituto Universitário de Lisboa. Departamento de Antropologia. Lisboa. 2017 Edições 70.2010.

HUSSERL, E. A ideia da fenomenologia. Lisboa: Edições 70, 2001.

LANGER, Johnni. Símbolos religiosos dos Vikings: Guia iconográfico. História, imagem e narrativas, v. 11, 2010, p. 1-28.

LEHTOLA, Veli-Pekka. (s.d.). Sami on the stages and in the zoos of Europe in Onthestages, Giellagas institute at the University of Oulu. Uleåborg, Finland. p.324-353 (s/d).

LIGIÉRO, Zeca. Estudos das performances brasileiras. Rio de Janeiro: Garamond, 2011.

MATTOS, CLG. A abordagem etnográfica na investigação científica. In MATTOS, CLG.; CASTRO, PA. (Orgs). Etnografia e educação: conceitos e usos. Campina Grande: EDUEPB, 2011. 
MERLEAU-PONTY, Maurice. Signos. São Paulo: Martins Fontes, 1991.

OLIVEIRA. Ricardo Wagner Menezes de Oliveira. Feras Petrificadas: $\mathrm{O}$ simbolismo religioso dos animais na Era Viking. Dissertação. Mestrado em Ciências das Religiões. Programa de Pós-Graduação em Ciências das Religiões. João Pessoa: 2016.

ORGANIZAÇÃO INTERNACIONAL DO TRABALHO. OIT 169. Available at: http://www.planalto.gov.br/ccivil 03/ _ato2004-2006/2004/decreto/d5051.htm. Accessed on: May 7, 2020.

PEIRCE, C. S. Semiótica e filosofia. Introdução de Octanny Silveira de Mota e Leonidas Hegenberg. São Paulo: Cultrix, 2010.

RICOEUR, P. Teoria da interpretação: o discurso e o excesso de significação. Lisbon: Tradução Magda Lopes. 3a ed. Porto Alegre: Armede, 2010.

TSIOUVALAS, Apostolos. Não Desperte a Rávga de Repparfjord: contação de Histórias de Sámi para Discutir a Disposição de Resíduos de Mineração de Nussir ASA. 2020. Dissertação de Mestrado. UiT Norges arktiske universitet. Available at: https:// hdl.handle.net/10037/18683. Accessed on Sept. 23, 2020.

VISITTROMS $\varnothing$. Portal VisitTromso: Imagens. Available at: https://www.visittromso.no/. Accessed on: May 2, 2020. 